\title{
Engaging Women in Computer Science - Past, Present and Future
}

\author{
Claudia Bauzer Medeiros \\ Institute of Computing, University of Campinas (UNICAMP), \\ Campinas, Brazil
}

\begin{abstract}
This short paper presents an informal, personal view of factors that may help - or prevent women to embrace careers in computing. Based on the author's professional and personal experience, it mixes facts with conjectures on how we may work towards a more genderdiverse future, with the help of scientific societies.
\end{abstract}

\section{Introduction - a story}

Let me start by telling a story. On January $2020 \mathrm{I}$ was at the Paris CDG airport, waiting for a flight to Washington DC. A hostess approached me and said "I know what you would like to read" - and gave me a copy of Paris Match. For those who do not know it, this is a weekly news magazine, full of glossy pictures, with many reports on royal families, famous socialites, recent movies and spectacles, society news, and such. Not really what I would choose. But then, I thought, why not, and started going through it. Fateful decision - it made me completely change this short paper!

The first 2 pages had an interview with French feminist comics illustrator, Pénelope Pagieu, who became a national bestseller with her comic book Les Culottées. This was subsequently translated to English as the graphic novel Brazen: Rebel Ladies Who Rocked the World. It has been widely acclaimed for its content depicting women who dared change the world. For context, we should keep in mind that illustrated comic books (bande dessinée in French) are a serious part of French literature, and widely read all over the country by adults and children alike. Ms. Pagieu's works have thus been acclaimed by intellectuals as quality writing with women at the center, but also widely ready by tens of thousands of young girls in France, who are inspired by her heroines. Her Paris Match interview starts with a very interesting sentence "Quand j'étais petite, les héros des BDs étaient Tintin et Asterix, des mecs..." (When I was a little girl, comic heros were Tintin and Asterix - only men). And she proceeds to tell how this helped her decide to write stories with girls and women heroines and adventurers, thereby helping her female readers have a "yes, you can" view of the world.

Her interview made me go back to my childhood. And so it was that, thanks to my unexpected encounter with Paris Match and Ms. Pagieu, this short paper became something completely different from what I intended it to be when Dra. Rosiane de Freitas invited me to write it.

\section{First impressions matter - or, on how families are fundamental to one's careers and outlook on life}

What did I read, and did this influence me in deciding to become a computer scientist? No; what happened is that I was lucky to have two wonderful role models - my parents. They were very caring and hardworking (my father, a doctor; my mother, a teacher who later became a university professor). Both loved playing with their 3 children, always talking about interesting stuff - in the sciences, in history and literature. Reading was stimulated as a fun activity - mysteries, adventure tales, history, mythology, fables, fairy tales. What really mattered was that our education was genderless, in the sense that there was never any mention of "this is for boys, this is for girls": studying is important, working is important, respecting others is important. Self-sufficiency was also something they insisted on: for instance, when I bought my first car, my father made me learn how to change a tire.

The three of us liked mathematics, so that at the end my brother became a professor in aeronautical engineering, and my sister a Math professor. Liking mathematics most certainly influenced my career choices. Nevertheless, I also liked to knit and embroider (and actually embroidered a lot until I left Brazil for my Ph.D. in Canada). At that time, I used to compare intricate embroidering to designing algorithms... 
So, conjecture number one: CLEI and LAWCC should try to engage families in their activities, attracting girls by attracting parents. This conjecture is in fact embraced by a large number of experts in the field - the first thing to do is to change learning environments at the familiar level. The Brazilian Computer Society (SBC) is doing a very good job in that direction, which are bearing fruit, as reports show.

\section{What makes a woman decide to become a computer scientist?}

Many of my younger woman colleagues credit role models for their choice of computing careers. But how did $I$ get into computing? Three factors, I think: the way I was brought up, love of maths and non-discriminating work and study environments. I talked about the first two factors in the previous section. Let me now present the third factor - which is something CLEI and its member societies might propitiate by continuing to promote its many events and involve faculty and enterprises in an effort to show the advantages of changing work and research environments.

I entered an excellent university, PUC-Rio, to get a degree in Engineering. There, I had my first programming course, in 1972, and got attracted to programming, which allowed to transform mathematical abstractions into palpable results. The abstract would become concrete - yes, though only after perforating hundreds of cards, and waiting for one day to see the result, often frustratingly wrong.

While finishing my Electrical Engineering degree, I had the opportunity of getting an internship in systems programming, as an operating systems engineer, and fell in love with IBM 360 Assembler. From then on, it was a point of no return. I worked as a systems analyst for 4 years, while getting an MSc in Computer Science from PUC-Rio. As an analyst, I worked in a male-only environment but was never treated as someone inferior or different, or less worthy. At PUC-Rio, all CS faculty were male, but again I never felt different - we must also recall that, at that time, there were many women students in computing. Being respected at the university, and at work, made all the difference.

What lessons from my personal history would serve to help attract women to computing? First, education and home environment play a very important role in breaching the gender divide. Second, role models matter - and who better than my working mother, a pioneer in her work in Brazil? Third, study and job environments are fundamental to attracting and maintaining women as productive professionals. So, in CLEI we should continue to work towards engaging girls; but we should also strive to engage the parents, change work environments, and change the way faculty looks at initiatives to bring more women into computing. In short, ADVOCACY is a keyword.

In our advocacy work, we must consider the changing face of computing. Sexual (and moral) harrassment are, sadly, a huge problem. I never had to face such issues, but in my university in Brazil I see this happening often - not only against women, but against "the other". Again, we have to combat such attitudes, which are frequently acquired at an early age. Let us strive towards showing the advantages of a diverse work and study environment - not only for the social good, but as promoters of economic development and scientific progress.

\section{Back to the future}

For more than a decade, CLEI has done a wonderful job of getting more girls interested in computing professions - and so has SBC, but also ACM or IEEE. But yet we keep hearing reports from young professionals about discrimination, unequal salaries and opportunities, and the importance of group support.

We all know that the first programmers were women, and are proud of women pioneers in the history of computing. Just as we know that in the 70's and even the early 80's there were lots of girls taking computing courses. But then, they "disappeared". Why? There are many theories, but no definite answer. US job statistics show that the number of women in computing is increasing progressively, pushed by cultural changes and market needs. Are we going back to the future? At least in my university this seems to be so. This is, I believe, due to several causes.

First, an acknowledgement by society (supported by serious comprehensive scientific studies) of the importance of diversity in the work environment to achieve better quality results - in science, industry, innovation. Second, the emergence of very many new exciting research and work opportunities, with new professions popping up every year, all of which requiring computing knowledge. Third, at least in western culture, an increasing awareness of the equality of women - intellectually and capacity-wise. So, whereas in the past "human computers" executed manual, tiring, exacting work, and thus one would recruit women (inferior, cheap human labor), now computing requires diversity, innovation, and thinking out of the box. Women are little by little considered important (and even essential) to contribute to this new environment - so much so that in many IT companies they are actively recruited. 
But we still have a problem: the perception (by girls, and their families) that computing jobs are not very interesting, "nerd-like", and "do not involve dealing with real societal problems". Also, unfortunately, often families still bring children up to follow preconceived gender roles. Thus the importance of work such as that fostered by CLEI or SBC.

A new danger are the problems caused by fake news, unethical algorithms, and irresponsible use of data. Many youngsters are put off by computing professions, claiming that they are evil and bad to our society. Thus, our advocacy of computing professions and research must reach another level, and seriously discuss the ethical issues, and the importance of having responsible professionals in ensuring a quality future for society.

The \#metoo movement has created a wave of awareness against sexual harassment, empowering voices that were kept silent for a long time. Are there exaggerations? Perhaps, in some cases. How can we, computer scientists, promote a similar movement towards getting everyone in the world aware of the relevance of getting more women to work in related fields?

These are among the many challenges that we and the next generations will have to face, so that advocacy will no longer be needed. And LAWCC and similar events and initiatives will become historical curiosities. "Once upon a time, a long, long time ago, there were almost no women in computing. And lots and lots of people worked very hard to change that state of things." This is the beginning of a story that I would love to read.

\section{Afterthoughts on reading and other kinds of advocacy}

Back to the Paris Match story, that showed me not to have preconceived ideas about reading material, what am I reading today? A wonderful book - Angela Carter's Book of Fairy Tales. Angela was an English novelist and writer, who wrote many feminist works. Her book is a collection of hundreds of fairy stories from all over the world, in which women are the heroines, the winners, the role models. Fairy stories originate from old folk tales. And this book shows how women, throughout hundreds of generations, are praised for their resourcefulness, intelligence and work. Perhaps, together with the French comic, we should give children these stories to read?

And, since we are talking about the future, what about advocating in favor of senior computer scientists? If I have never felt discriminated against because I am a woman, I now feel the discrimination against someone who is over 65 and insists in computing research. My older colleagues comment on this as well. Since I am 65, I obviously must be doing old and worthless stuff - this is how I often feel treated. But this suggestion should not be the subject of this paper, and please forget that I mentioned it!!!!!

\section{Thanking people}

My career has always benefited from interactions with marvelous people. I start by thanking my wonderful graduate students, with whom I have worked for almost 35 years, for their questions, friendship and collaboration. I have had the luck of working with many great colleagues, from several disciplines, with whom I continue to have fruitful scientific and friendly interactions. I profited from the work environment at UNICAMP, and also the unique opportunities I have had while serving in FAPESP committees. Funding Brazilian agencies CNPq, CAPES and FAPESP provided me with much needed support. Last but not least, my thanks to my MSc supervisor, Carlos Lucena, from PUC-Rio, and my Ph.D. supervisor Frank Wm Tompa, from the University of Waterloo, role models for integrity in research and respect of students.

And many thanks to Rosiane de Freitas for inviting me, and for her patience in waiting for this text.

\section{Acknowledgment}

Work partially financed by FAPESP/CEPID CCES (2013/08293-7), CNPq grant 305110/2016-0 and CNPq Arapuan project number 428459/2018-8. 